\title{
MODEL OF LOCAL POPULATION PERCEPTION IN SUPPORTING COASTAL TOURISM DEVELOPMENT AND PLANNING IN BALI
}

\author{
I Made WARDANA* \\ Udayana University, Faculty of Economics and Business, \\ Bukit Jimbaran Bali, Indonesia 80361, e-mail: wardana@unud.ac.id \\ I Wayan Mudiartha UTAMA \\ Udayana University, Faculty of Economics and Business, \\ Bukit Jimbaran Bali, Indonesia 80361, e-mail: wardana@unud.ac.id \\ I Putu ASTAWA \\ State Polytechnic of Bali, Tourism Department, Bukiti Jimbaran, \\ Bali, Indonesia 80361, e-mail: putuastawa1@pnb.ac.id
}

\begin{abstract}
Citation: Wardana, I.M, Utama, I.W.M \& Astawa, I.P. (2018). MODEL OF LOCAL POPULATION PERCEPTION IN SUPPORTING COASTAL TOURISM DEVELOPMENT AND PLANNING IN BALI. GeoJournal of Tourism and Geosites, 23(3), 873-880. https://doi.org/10.30892/gtg.23321-335

Abstract: The aims the research is to investigate the perception of local population about the benefits of personal received from the Coastal Tourism. This study also proves the effect of personal benefits on the support of coastal tourism development and planning in Bali. This research is a quantitative research and data were collected through distributing questionnaires to predefined respondents. Coastal Tourism had a positive impact and supported the development and planning of Coastal Tourism in Bali. The negative impact perceptions did not significantly affect on the Coastal Tourism development.
\end{abstract}

Key words: Personal Benefits, Development Support, Planning Support

\section{INTRODUCTION}

Tourism is one sector of the economy in Bali, that has been proven to provide benefits both to the surrounding community, and to the government. Countries that have tourism potential have been vying to utilize the tourism sector to generate foreign exchange, because the tourism sector has more export dimensions. In addition, tourism is believed to in addition to generate foreign exchange (economic impact), can also cause socio-cultural and environmental impacts. Bali is one of the world famous tourist destinations that highlight the cultural tourism based on the Hindu religious pilot of Trihita Karana. Bali has a variety of tourism resources, namely Cultural Tourism, Coastal

\footnotetext{
* Corresponding author
} 
Tourism, Nature Tourism, Ecotourism, Agro Tourism, Convention Tour, Village Tour and more. The beginning of tourism in Bali is known by tourists, one of which is the beauty of beaches such as Kuta beach and Sanur beach. Bali has 10 very beautiful beaches, Coastal Tourisms, which are the target of domestic and foreign tourists visits, namely Tanjung Benoa Beach, Pandawa Beach, Dreamland Beach, Legian Beach, Nusa Dua Beach Bali, Sanur Beach, Tanah Lot Beach, Jimbaran Beach, Kuta Beach Bali and Lovina Beach.

The development of the Coastal Tourism should provide an opportunity for the community, especially for the local population to engage in tourism economic activities, thus improving their welfare. The involvement of the local people in tourism is indispensable because the local people are the major stakeholders in the development of tourism destinations (Hanafiah et al., 2013). Their perception is very important to evaluate the current situation of the destination (Cottrell \& Vaske, 2006). Research on attitudes to local people in tourism development becomes an interesting topic for researchers, as there is a belief that local people will support tourism development if they receive a positive impact from tourism Pavlic et al., (2015).

Based on the above description, research on the perception of local population in supporting the development and planning of Coastal Tourism in Bali is very relevant. This study refers to Perdue et al., (1990, 1991) model, which has never been applied in Bali Coastal Tourism research. This research explores the perception of local population about whether the benefits of tourism can be received in their life in the area of Coastal Tourism. The study will also explore the extent of their support and involvement in Coastal Tourism development and planning. This research is supported by a team of researchers that have expertise in the field of tourism management so that it is expected to provide value to the stakeholders.Tourism is a complex industry, providing employment opportunities, sources of tax revenues and involves various economic activities. Tourism is an activity related to social, cultural, economic and environmental activities (Godfrey \& Clarke, 2000; Ilieș \& Ilieș, 2015).

Tourism has become a source of socio-economic change in many developing countries. Tourism is multi sector, and can be a mean of economic exchange, social and cultural benefits, and has many aspects and types (Mowforth \& Munt, 2003). Tourism growth has a significant effect on economic benefits such as creating employment and additional income, in both host countries and countries of origin (Delibasic et al., 2008).

Tourism is an industry that has an environmental, social, cultural and economic impact. The phenomenon of tourism needs to get serious attention especially in planning, for proper decision making (Belisle \& Hoy, 1980; Liu, \& Var, 1986; Liu \& Var; 1987; Sheldon \& Var, 1984). The study generally recognizes that tourism has a positive impact but on the other hand, tourism also has negative impacts on social, environmental issues, such as congestion, crime, security issues and pollution (Kovács et al, 2013; Rogerson, 2018). There are several ways to categorize the impact of tou rism. Kreag (2001) in his research book, the impact of tourism is divided into seven general categories of economic, environmental, social and cultural, noise and congestion, service, taxes and public attitudes (Archer \& Cooper 1994).

Inskeep (1991) argues about the impact of tourism written in a book entitled Integrated Development and Sustainable Tourism Planning. The impact of tourism is separated into economic, political, socio-cultural, environmental and ecological impacts. The impact of tourism is broadly divided into two categories, namely economic and environmental impacts. However, the impacts of tourism are most often grouped into three categories, which are economic impacts, physical or environmental impacts, and social impacts (Ap \& Crompton, 1998; 1992; Mathieson \& Wall, 1982). Since 1970, many studies have analyzed the attitudes and perceptions of the community towards tourism 
development. The studies initially investigated the positive impacts of the tourism economy and ultimately on the attitudes of local population and toward the other impacts of tourism. Pizam (1978) stated the importance of analyzing citizens' attitudes toward the negative impacts of tourism development as well as the need to provide a solid foundation for the development of high-quality tourism to satisfy both citizens and tourists alike. In the 1980 s scientists continued to analyze the attitudes of society, to the economic and social, positive and negative impacts of tourism through the application of factor analysis with inadequate reliability performed by Belisle and Hoy (1980). Based on the THAID model, Brougham and Butler (1981) prove that the positive and negative effects of tourism do not have the same impact on all the locals.

They also found significant differences in the impact of tourism on the nature of the local population. Using the same methodology Sheldon \& Var (1984) point out six key determinants for residents in North Wales: negative social impacts, economic income, visitor stereotypes, apartment purchases, cultural impacts and environmental impacts of tourism development. The personal benefits that local population receive from tourism activities are related to their support for development. Research on the personal benefits of tourism impact has been made in China by Yingzhi et al., (2014). In analyzing the impacts of tourism on the individual benefits of the local population, it was based on the exchange theory developed by George Homans in 1960. Social Exchange Theory is basically an individual rational behavior, both to gain respect and to avoid punishment. Social Exchange theory emphasizes the role and function of humanitarian and emotional needs in personal communication and social exchange process. Yingzhi et al., (2014) have found that there is a significant relationship between the perception of personal benefits and the impact of tourism in China. Personal benefits relate to the benefits of resources, environmental protection, participation in decision-making in tourism.

The local resident is the most essential determinant of the sustainability of tourism destinations. According to McKercher (2003), sustainable tourism development can be identified as four pillars, namely (1) sustainable economy, i.e. economic efforts to generate profits now and in the future, (2) sustainable ecology that is the harmonious development with the essence of ecological processes, 3) a sustainable culture is the development that improves the quality of life, harmonious with the culture and values as well as maintaining with the self-identity of the community and (4) sustainable society is development designed to provide economic benefits to the local population and to increase its material well-being. The four pillars indicating the development of sustainable tourism industry is an effort to balance the economic value derived by the tourism industry and the benefits gained by the local population, in the preservation of the environment and the preservation of socio-cultural values of local population.

In 1990 the interest for research in the field of tourism increased significantly. But there are different approaches and methodologies to identify the problem. Perdue et al., (1990) examined the model of the perception and impact of tourism as well as citizens' support for tourism development. The findings ware showed that as long as people enjoy the personal benefits of tourism development, they will support the tourism development policies. By applying the Social Exchange Theory, Ap (1992) analyzes the reasons for the positive and negative perceptions of the impact of tourism on the local population. The results of the study were found that as long as the exchange of resources between residents and tourists is high and balanced, then the impact of tourism will be positive from the perspective of the local population. Sook-Fun \& MayChiun (2105) in his research on the involvement of local people in sustainable rural tourism in Kuching, provide strong evidence that the importance of local involvement in the development of sustainable rural tourism. Research on the perception of local 
populations will arouse the interest of tourism stakeholders about the importance of local people's involvement in achieving sustainable tourism development.

Community-based tourism development is development by involving local communities as key stakeholders (Manjula \& Rinzing, 2014). However, in general, bottom-up planning concepts are usually implemented by top-down policy due to lack of awareness in some communities. Communities participating in planning to implementation levels are often catalyzed by external forces such as non-governmental organizations, incentives for local populations, and little exploration of what people think about their role in tourism development.

\section{MATERIALS AND METHODS}

This research uses a quantitative approach based on the principle of positivism. This study examines perceptions of the impact of tourism on local populations in support of Coastal Tourism development and planning. The conceptual framework in this study refers to the Perdue Model et al., (1990). In this study variable personal characteristics are not considered because it is assumed homogeneity level is relatively high. Based on previous research from Yingzhi et al., (2014) found that there is a significant relationship between the perception of personal benefits and the impact of tourism in China. Personal benefits relate to the benefits of resources, environmental protection, participation in decision making in tourism. Mello et al., (2015) found that the benefits of a person had a significant positive effect on the perception of the positive impact of tourism.

The benefits of personal positive impact and negative impact are able to predict the development support. Furthermore, it was found that the benefits of a person development support were able to predict planning support coastal tourism. From the above analysis can be formulated research hypothesis as follows: personal benefits have a positive and significant impact on the positive impacts and negative impacts of the Coastal Tourism; personal benefits have a positive and significant impact on Coastal Tourism development support; positive impacts and negative impacts have positive and significant impacts on Coastal Tourism development support; development support has a positive and significant impact on Coastal Tourism planning support.

The population in this study are local residents in 10 Coastal Tourism site in Bali, namely: Tanjung Benoa Beach, Pandawa Beach, Dreamland Beach, Legian Beach, Nusa Dua Beach Bali, Sanur Beach, Tanah Lot Beach, Jimbaran Beach, Kuta Beach Bali and Lovina Beach. The sample size is set according to the formula 5 to 10 times the number of research kostruk indicators. Based on the provisions of the formula, the sample size was determined to be $5 \times 24$ (number of indicators) $=96$ rounded to 100. Sampling technique using Non Probability Sampling approach with purposive sampling technique. Data were collected by distributing questionnaires to respondents. Descriptive analysis is used to determine the characteristics of respondents and description of respondents' perceptions of research constructs. Hypothesis test using Structural Equation Modeling (SEM), with Partial Least Square (PLS) approach and Smart PLS version 3 software application program.

\section{RESULTS DISCUSSIONS}

Most of respondent's age spreads in the range of age 20 years to 30 years (54\%), education respondents spread mostly at high school education level (59\%). Most of the respondents' occupations (62\%) are related to Coastal Tourism. In general, respondents give good perception to research construct. The research constructs are Personal Benefit (PER.BENF), Positive Impact (POS.IMP), Development Support (DEV. SUPP), and Planning Support (PLN.SUPP). However, on the other hand, the (NEG.IMP) did not 
agree that Coastal Tourism has been resulted the negative impacts. This also means, the Coastal Tourism in their residence area provides personal benefits, positive impact, support the development and planning of Coastal Tourism in Bali. The result of analysis by using Smart-PLS3 program shows that all factor loading values $>0.60$ with PV $<0.05$, its means that all construct indicators in this research can be considered valid to meet the covergent validity criteria as shown in the following table 1.

Table 1. Outer Model (Data Source: Output Smart-PLS3, 2018)

\begin{tabular}{|c|c|c|c|c|c|}
\hline Variabel & $\begin{array}{c}\text { Original } \\
\text { Sample }(\mathrm{O})\end{array}$ & $\begin{array}{c}\text { Sample } \\
\text { Mean }(\mathrm{M})\end{array}$ & $\begin{array}{c}\text { Standard } \\
\text { Deviation (STDEV })\end{array}$ & $\begin{array}{c}\text { T Statistics } \\
(\mid \mathrm{O} / \mathrm{STDEV})\end{array}$ & P Values \\
\hline X1.1=> PER.BENF & 0,692 & 0,675 & 0,095 & 7,250 & 0,000 \\
\hline X1.2=> PER.BENF & 0,647 & 0,627 & 0,113 & 5,742 & 0,000 \\
\hline X1.3=> PER.BENF & 0,661 & 0,639 & 0,134 & 4,930 & 0,000 \\
\hline X1.4=> PER.BENF & 0,710 & 0,700 & 0,082 & 8,676 & 0,000 \\
\hline X1.5=> PER.BENF & 0,654 & 0,662 & 0,085 & 7,663 & 0,000 \\
\hline Y1.3=> POS.IMP & 0,703 & 0,684 & 0,110 & 6,363 & 0,000 \\
\hline Y1.4=> POS.IMP & 0,825 & 0,827 & 0,052 & 16,001 & 0,000 \\
\hline Y1.5=> POS.IMP & 0,673 & 0,653 & 0,133 & 5,054 & 0,000 \\
\hline Y2.1=> NEG.IMP & 0,624 & 0,614 & 0,141 & 4,438 & 0,000 \\
\hline Y2.2=> NEG.IMP & 0,827 & 0,815 & 0,076 & 10,880 & 0,000 \\
\hline Y2.3=> NEG.IMP & 0,838 & 0,826 & 0,075 & 11,237 & 0,000 \\
\hline Y2.5=> NEG.IMP & 0,650 & 0,616 & 0,180 & 3,622 & 0,000 \\
\hline Y3.1=> DEV.SUPP & 0,751 & 0,748 & 0,068 & 10,992 & 0,000 \\
\hline Y3.2=> DEV.SUPP & 0,794 & 0,785 & 0,082 & 9,686 & 0,000 \\
\hline Y3.3=> DEV.SUPP & 0,708 & 0,692 & 0,100 & 7,051 & 0,000 \\
\hline Y3.4=> DEV.SUPP & 0,693 & 0,673 & 0,109 & 6,382 & 0,000 \\
\hline Y4.1=> PLN.SUPP & 0,720 & 0,676 & 0,170 & 4,247 & 0,000 \\
\hline Y4.2=> PLN.SUPP & 0,786 & 0,738 & 0,162 & 4,909 & 0,000 \\
\hline Y4.3=> PLN.SUPP & 0,731 & 0,710 & 0,181 & 4,041 & 0, o00 \\
\hline Y4.4=> PLN.SUPP & 0,703 & 0,638 & 0,215 & 3,276 & 0,001 \\
\hline
\end{tabular}

\section{Discriminant Validity Test}

Discriminant Validity test shows (Table 2) that the square root value of AVE (0.738, $0.741,0.673,0.738,0.736)$ is greater than the correlation of each construct. Thus indicating that the proposed model is no problem seen from discriminant validity.

Table 2. Cross Loading (Data source: Output Smart-PLS3, 2018)

\begin{tabular}{|l|r|r|r|r|r|}
\hline \multicolumn{1}{|c|}{ Variable } & \multicolumn{1}{c|}{ Dev.Supp } & \multicolumn{1}{c|}{ Neg.Imp } & \multicolumn{1}{c|}{ Per.Benf } & \multicolumn{1}{c|}{ Pln.Supp } & Pos.Imp \\
\hline DEV.SUPP & 0,738 & & & & \\
\hline NEG.IMP & $-0,150$ & 0,741 & & & \\
\hline PER.BENF & 0,365 & $-0,349$ & 0,673 & & \\
\hline PLN.SUPP & 0,279 & $-0,303$ & 0,519 & 0,738 & \\
\hline POS.IMP & 0,405 & $-0,247$ & 0,522 & 0,343 & 0,736 \\
\hline
\end{tabular}

\section{Inner Model Feasibility Test}

\section{Q-Square (Predictive Relevance)}

Q-Square (Predictive Relevance) measures how well the observation value generated by the estimation model and its parameters. The Q-Square value $>0$ indicates the model has good predictive relevance. Conversely, if Q-Square < o indicates the model has poor predictive relevance. The Q-Square (Predictive Relevance) value can be calculated (Cottrell \& Vaske, 2006) as follows: 


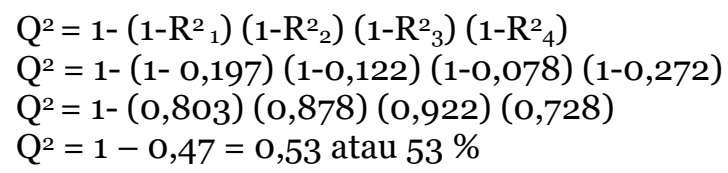

Based on the calculation of the Q-square is 0.53 or $53 \%$ which can be interpreted that the model has a very good observation value. This means that $53 \%$ of the relationships between constructs can be explained by the model, and the remainder is influenced by the constructs not examined in this study. The last one is to find the value of Goodness of Fit (GoF) which must be calculated manually (Cottrell \& Vaske, 2006) as follows:

$$
\begin{aligned}
& \text { GoF }=\sqrt{ } \text { AVE X R } \\
& \text { GoF }=\sqrt{ } \text { o,659 X } 0,167=0,33
\end{aligned}
$$

According to Tenenhaus (2004), GoF small value $=0.1$, GoF medium $=0.25$ and large $\mathrm{GoF}=0.38$. From the results of the calculation of GoF, which obtained the numbers of 0.38 (medium-strong) and Q2 by 53\% gives an indication that the quality of research models eligible forwarded for the phase of hypothesis testing.

\section{Specific Indirect Effects}

This analysis aims to determine the significance of indirect relations between variables.

Table 3. Specific Indirect Effects (Data source: Data processed, 2018)

\begin{tabular}{|l|c|c|c|c|c|}
\hline \multicolumn{1}{|c|}{ Variable } & $\begin{array}{c}\text { Original } \\
\text { Sample }\end{array}$ & $\begin{array}{c}\text { Sample } \\
\text { Mean }\end{array}$ & STDV & T-Value & P-Value \\
\hline PER.BENF $=>$ NEG.IMP => DEV.SUPP. & 0,002 & 0,002 & 0,047 & 0,033 & 0,974 \\
\hline PER.BENF $=>$ POS.IMP => DEV.SUPP. & 0,153 & 0,165 & 0,070 & 2.178 & 0,030 \\
\hline $\begin{array}{l}\text { PER.BENF }=>\text { NEG.IMP }=>\text { DEV.SUPP }=> \\
\text { PLN.SUPP }\end{array}$ & 0,000 & 0,001 & 0,016 & 0,027 & 0,979 \\
\hline PER.BENF $=>$ DEV.SUPP $=>$ PLN.SUPP. & 0,059 & 0,075 & 0,049 & 1,209 & 0,227 \\
\hline $\begin{array}{l}\text { PER.BENF }=>\text { POS.IMP }=>\text { DEV.SUPP }=> \\
\text { PLN.SUPP }\end{array}$ & 0,043 & 0,054 & 0,030 & 1,445 & 0,149 \\
\hline
\end{tabular}

Teble 3 shows that there is only one significant indirect relationship that is significant: Personnel Benefit $=>$ Positive Impact $=>$ Development Support where PValue $0.030<0.05$. Thus it can be stated that the Positive Impact construct fully mediates the relationship between Personnal Benefit and Development Support.

\section{Hypothesis testing}

The results of the analysis show that two hypotheses were rejected are the influence of Negative Impact on Development Support and the influence of Personal Benefit on Development Support. While four hypothesis were accepted that is the influence of Development Support on Planning Support, the influence of Personal Benefit on Negative Impact, the influence of Personal Benefit on Positive Impact and Positive Impact influence on Development Support. Through the bootstraping process in Smart PLS program 3, the hypothesis test can be seen in Table 4 .

The research results showed that the personal benefits have a strong influence on the positive impact of coastal tourism development. The relationship means, the greater the private benefit received by the local population, the greater the positive impact felt by the local population from the development of the Coastal Tourism. The research results showed that the Personal Benefits do not significantly affect the support of coastal tourism development. This relationship means that the increased personal benefits received by local residents are not followed significantly by the increased support of coastal tourism development (Kuqi, 2018). 
Model of Local Population Perception in Supporting Coastal Tourism Development and Planning in Bali

Tabel 4. Path Coefficient Sumber: Output Smart-PLS.3, 2018

\begin{tabular}{|l|c|c|c|c|c|}
\hline \multicolumn{1}{|c|}{ Variable Relationships } & $\begin{array}{c}\text { Original } \\
\text { Sample(O) }\end{array}$ & $\begin{array}{c}\text { Sample } \\
\text { Mean (M) }\end{array}$ & $\begin{array}{c}\text { Standard } \\
\text { Deviation(STDEV) }\end{array}$ & $\begin{array}{c}\text { T Statistics } \\
(|\mathrm{O} / \mathrm{STDEV}|)\end{array}$ & $\begin{array}{c}\text { P } \\
\text { Values }\end{array}$ \\
\hline Development Support $=>$ Planning Support & 0,279 & 0,327 & 0,095 & 2,928 & 0,004 \\
\hline Negative Impact => Development Support & $-0,004$ & $-0,002$ & 0,128 & 0,035 & 0,972 \\
\hline Personnel Benefit $=>$ Development Support & 0,211 & 0,225 & 0,117 & 1,796 & 0,073 \\
\hline Personnel Benefit => Negative Impact & $-0,349$ & $-0,369$ & 0,091 & 3,829 & 0,000 \\
\hline Personnel Benefit =>Positive Impact & 0,522 & 0,550 & 0,065 & 8,085 & 0,000 \\
\hline Positive Impact=.>Development Support & 0,294 & 0,298 & 0,120 & 2,448 & 0,015 \\
\hline
\end{tabular}

The Personal Benefits do not affect significantly the support of coastal tourism development in Bali. This relationship means that the increased personal benefits received by local residents are not followed significantly by the increasing support of coastal tourism development (Ilieș \& Ilieș, 2015). The positive impact of coastal tourism development has a significant effect on the support of coastal tourism development in Bali. The higher the positive impact of Coastal Tourism, the higher is the support of development of Coastal Tourism in Bali.The results of this research also indicate that the development support has significant effect on the support of coastal tourism planning in Bali. The higher the development support effort, the higher the motivation in supporting the planning of Coastal Tour in Bali by local people.

\section{Research Implications}

The negative impact was found to be insignificant in efforts to support the development of coastal tourism in Bali. Personal benefits do not have a positive and significant impact on the support efforts of Coastal Tourism development in Bali. The rejection of the two proposed hypotheses is a phenomenon that needs to be investigated through further research. The research results also indicate that the negative impacts are still smaller than the positive impacts of coastal tourism activities in Bali, so the intention to support Coastal Tourism by local residents is ongoing. The implications of this study's findings are that there should be an ongoing reduction of the negative impacts, through the indications that shape the construct.

\section{CONCLUSION}

Local residents mostly feel that they have personal benefits, and they feel that Bali Coastal Tourism has a positive impact as well as a negative impact. They argue that development support and planning support from local people is urgently needed. Personal benefits can not directly grow the intention to support the development and planning of Coastal Tourism in Bali. Local residents' intends to support development and planning when they feel the positive impact of Coastal Tourism in Bali. Increase personal benefits for local people: Efforts to increase personal benefits are to provide local residents access to tourists, provide opportunities in the Coastal Tourism sector to local residents, conserve the environment, engage in solving coastal tourism problems, and provide economic benefits. Increase positive impact for local people: Efforts that can be done to enhance the positive impact of coastal tourism development in Bali are to provide economic benefits to small businesses, provide landscapes and recreation, maintain cultural identity of the population, improve the quality of public services and improve living standards of local people.

\section{Aknowlegments}

The authors would like to send their gratitude to the Indonesian Government for the research funding as well as to the head of $\mathrm{P}_{3} \mathrm{M}$ that gave motivation to complete the research. Also, the authors would like to thanks the local Goverment for their participation in the model test. 


\section{REFERENCES}

Ap, J., \& Crompton, J. L. (1998). Developing and testing a tourism impact scale. Journal of travel research, $37(2), 120-130$.

Ap, J. (1992). Residents' perceptions on tourism impacts. Annals of tourism Research, 19(4), 665-690.

Archer, B., Cooper, C., \& Ruhanen, L. (2005). The positive and negative impacts of tourism. Global tourism, 3, 79-102.

Belisle, F. J., \& Hoy, D. R. (1980). The perceived impact of tourism by residents a case study in Santa Marta, Colombia. Annals of tourism research, 7(1), 83-101.

Brougham, J. E., \& Butler, R. W. (1981). A segmentation analysis of resident attitudes to the social impact of tourism. Annals of tourism research, 8(4), 569-590.

Cottrell, S. P., \& Vaske, J. J. (2006). A framework for monitoring and modeling sustainable tourism. E-Review of Tourism Research, 4(4), 74-84.

Delibasic, R., Karlsson, P., Lorusso, A., Rodriguez, A., \& Yliruusi, H. (2008). Quality of life and tourism in Budečsko. Retrieved January, 5, 2011.

Godfrey, K., \& Clarke, J. (2000). The tourism development handbook: a practical approach to planning and marketing. Burns \& Oates.

Hanafiah, M. H., Jamaluddin, M. R., \& Zulkifly, M. I. (2013). Local community attitude and support towards tourism development in Tioman Island, Malaysia. Procedia-Social and Behavioral Sciences, 105, 792-800.

Homans, G. C. (1960). The Human Group, New York: Har-court, Brace \& World.

Ilieș, G., \& Ilieș, M. (2015). Identity based geo-and tourism branding strategies derived from rural Maramureș land (Romania). GeoJournal of Tourism and Geosites, 8(2), 179-186.

Inskeep, E. (1994). National and regional tourism planning: methodologies and case studies. Routledge. Life. Journal of China Research, 10, 142-164.

Kovács, Z., Wiessner, R., \& Zischner, R. (2013). Urban renewal in the inner city of Budapest: Gentrification from a post-socialist perspective. Urban Studies, 50(1), 22-38.

Kreag, G. (2001). Tourism Imfacts. Publication Number: T 13. University of Minnesota

Kuqi, B. (2018). Teoritical Approach Concerning The Development Of Sustainable Tourism As Tourist Destination In Kosovo. GeoJournal of Tourism and Geosites, 22(2), 489-496

Liu, J., Sheldon, P., \& Var, T. (1987). A Cross- National Approach To Determining Residents Perceptions Of The Imfact Of The Tourism On The Environment. Annal Of Tourism Research 14 (1): 17-37

Liu, J.C., \& Var, T. (1986), Resident Attitudes Toward Tourism Impact in Hawaii, Annals of Tourism Research, $13(2), 193-214$.

Manjula C., \& Rinzing L., (2014). Community Based Tourism Development in Sikkim of India V A Study of Darap and Pastanga Villages. Transational Corporation Review, 6 (3), 228-237.

Mathieson, A., \& Wall, G. (1982). Tourism: Economic Physical and Social Imfacts. London: Longman.

McKercher, B. (2003). Sustainable Tourism Development - Guiding Principles For Planning and Management. Presentation to the National Seminar on Sustainable Tourism Development. Bishkek, Kyrgistan, November 5-9, 6-7.

Mello, C. D., Chang, L. C., Kamat, K., Scaglione, M., Weiermair, K., \& Pillai, S. K. (2015). An Examination of Factors Influencing Residents Perception of the Impacts of Tourism in Goa. International Journal of Hospitality and Tourism Systems, 8(2).

Mowforth, M., \& Munt, I. (2003). Tourism and Sustainability. Development and New Tourism in the Third World. London, UK: Routledge Publishing.

Pavlić, I., Portolan, A., \& Puh, B. (2015). The Social Impacts of Tourism on Local Community's Quality of Life. Tourism in Southern and Eastern Europe, 3, 259-272.

Perdue, R. R., Long, P. T., \& Allen, L. R. (1990). Residents support for tourism development. Annals of Tourism Research, 17(4), 586-599.

Perdue, R. R., Long, P. T., \& Gustke, L. D. (1991). The effect of tourism development on objective indicators of local quality of life. Tourism: Building credibility for a credible industry. Paper presented at the The 22nd Annual TTRA Conference, Travel and Tourism Research Association, Salt Lake City, UT.

Pizam, A. (1978). Tourism's Impacts, The Social Costs to the Destination Community as Perceived by Its Residents, Journal of Travel Research, 16 (4), 8-12.

Rogerson, C. (2018). Local Economic Development in the Changing World: The Experience of Southern Africa. Routledge. Sheldon, P. J. \& Var, T. (1984). Resident attitudes to tourism in North Wales. Tourism Management, 5, 40-47.

Sook-Fun F. \& May-Chiun L. (2015). Community involvement and Sustainable Rural Tourism Development: Perspectives From The Local Communities. European Journal of Tourism Research, 11, 125-146.

Yingzhi G., Seongseop K., Yong C. (2014). Shanghai Residents' Perceptions of Tourism Impacts and Quality of Life. Journal of China Research, Vol 10 p. 142-164.

Submitted:

o8.09.2018
Revised:

23.11.2018
Accepted and published online

27.11.2018 